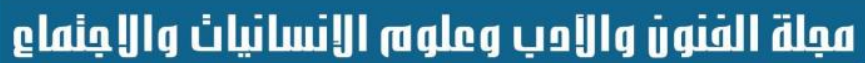 \\ Journal of Arts, Literature, Humanities \\ and Social Sciences
}

ISSN print: 2616- 3810

Volume 48

\section{Anticipatory of Self-Defence in International Law}

\author{
Hemn Khalid Ali \\ College of Law - Salahaddin University- Erbil - Iraq \\ Email:hemn.ali@su.edu.krd
}

\begin{abstract}
Throughout human history, the use of force has been the main option and means to settle disputes. However, with the development and change of human's way of thinking the use of force has declined as the only solution. This traditional way has been regulated and has to be used only in certain situations. For example, the Charter of United Nations has granted the right for using force as self-defence. There still is disagreement and doubts about using force against potential attacks and invasions between states. Although, in the era of mass destruction weapons and terrorism, as well as, tracing back to the customary rules; the anticipatory self-defence has been justified in international law. Yet, there isn't a consensus view and a general agreement to authorize this kind of self-defence
\end{abstract}

Keywords: Self-defense, Use of Force, The Anticipatory of self-defence. 


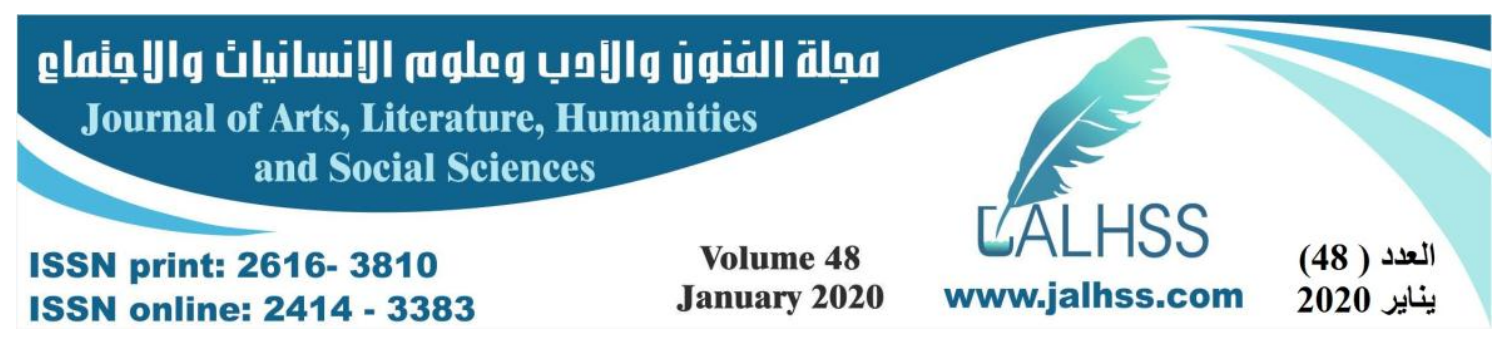

Introduction:

Throughout history, the use of force has been one of the means to resolve international crises. It was not the best way because the world suffered from a huge tragic such as atrocities, starvation and homelessness. The regulation of the use of force has become a concern for the international community. Efforts have been tried by an international organization like The League Nation and The United Nations in this field. The use of force has been banned; however state can use it as a right of selfdefence. It has been argued that a right of self-defence contains anticipatory selfdefence and pre-emptive self-defence. This paper will discuss the explanation of these rights in the light of current developments. The position of two main academic schools will be analysed. In addition, the justifications for this two counter opinion will be compared. Furthermore, the two significant areas, weapons of mass destruction and terrorist attacks, which have enormous impact on new understanding and conclusion for this right, will be highlighted.

\section{1- International Organizations and Conflict Prevention}

Before 1954 states had a right to resort the use of force as a means of selfdefence when an attack had occurred or to righting a large wrong. In this event, a war had been considered the just war. The concept of the use of force has changed after The League Nation was established (Hillier, 1998, 59). After the First World War, regulate the use of force became the most important issue for the international community. Consequently, the League of Nations was established in order to arrange the use of force (Abass, 2012, 348). The most important objectives of The League of Nations were to preserve peace, promote security and collaborative over the world and attempt to improve the work and life situation for individuals (Mendum \& Waugy, 2001, 16). However, the League of Nations is regarded as the first effort to regulate the use of force, but this attempt did not reach its aim (Abass, 2012, 349).

In fact, the attack was not banned under the League of Nations, states subject to esteem and maintains as against foreign hostility the regional safety. In case of any aggression or threat or danger, the Council will give advice for state was attacked about which action shall be performed (The League of Nations, Article 10). In relation to the right of self-defence, was not explicitly indicated, while this right was stated implicitly which can be deduced in Articles 10,12,15.The right of self-defence can be exercised by the member states once they faced an actual foreign aggression (Szabo, 2011, 86).

The United Nations Charter resulted from another attempt to regulate the use of force. The regulation in this Charter has a variation form and there is a primary difference with other regulations (Abass, 2012, 350-351). Under the UN Charter a states have been required to settle all inter-state dispute by peaceful means," All Members shall settle their international disputes by peaceful means in such a manner that international peace and security, and justice, are not endangered"( The United Nations Charter, Article 2(3)). In addition, it has been asserted that all states shall abstain from use force or threat in their international relationship, "All Members shall refrain in their international relations from the threat or use of force against the 


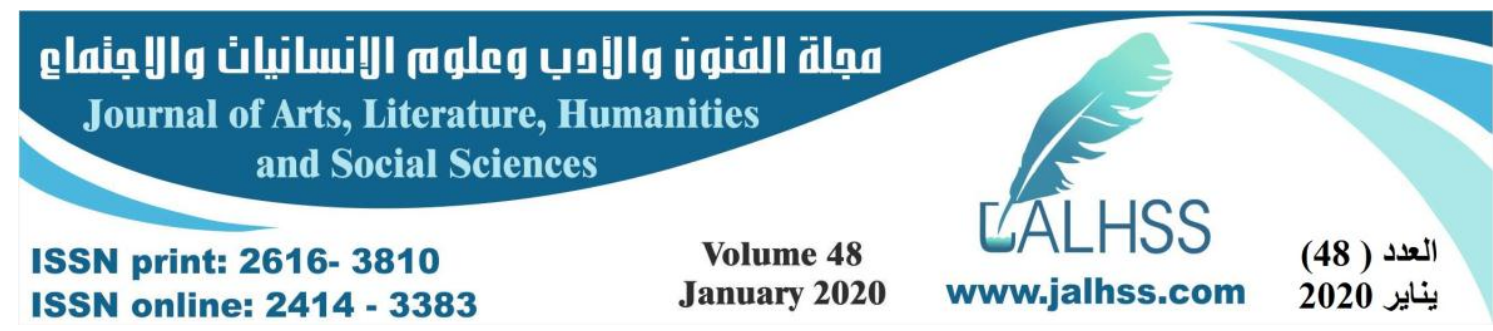

territorial integrity or political independence of any state, or in any other manner inconsistent with the Purposes of the United Nations"(The United Nations Charter, Article 2(4)). Furthermore, it has noted that the ban of the use force extended, it does not include prohibition the use of force only, it comprises the use of threat too (Wallace, 2005, 278).

On the other hand, the UN Charter allows the use of force as an exception in specific circumstances. Generally, there are three exceptions, use of force in selfdefence, use of force after authorization of the UN Security council and the use of force against the former enemy which have been stipulated in article 51, Chapter II and article 107 respectively (the last one is abolished) (Abass, 2012, 363). Article 51 has authorized state to resort use of force to protect them-selves against foreign armed attack; also a state can require other states to help, In addition, if the situation in a threat to international peace and security the Security Council can empower military intervention for humanitarian purpose (Aust, 2010, 210-211).

\section{2- The concept of Self-Defence and The Caroline Doctrine}

The concept of self-defence is one of aspects has created a much debate; the debate has revolved around a suitable application of the situation under which the right of self-defence can be exercised. Many states and academics have complained with International Courts of Justice about misapplication and misunderstanding of this concept. The interpretation of this concept has not been not far from the effects of political (Azubuike, 2011, 129).

The justification of the right of self- defence was stated under international customary law in the Caroline event in 1837. It is considered as the classic explanation of the right of self-defence The Caroline dispute created a customary principle for fixing whether preventive armed force is a legal means of self-defence. The case emerged when the steamship Caroline was seized and burned by military forces. This action was taken by the British without the knowing and assents of The Unite States government.

Canada rebelled from British power, and a number of Canadian revolutionary leaders succeed to arrange a force which was about a thousand to support their issue, the supporters were New Yorkers. On December 13, Navy Island was seized by these rebels; on 29 December passing British ship was fired by these rebels. At this time, men and munitions were ferried by Caroline "American steamboat". In a night raid the Caroline was attacked by British boatloads. This action was justified by British colonel on this ground to cut down equipping men and munitions to the rebel on Navy Island and to prevent the rebels to use any means in order to occupy the Canadian side of the river (Fitzgerald, 2008, 477).

During a number of connections which happened between the new U, S. Secretary of State Daniel Webster and the British Special Minister, Lord Ashburton. The former indicated the provisions in the international law of self-defence" necessity of self-defence, instant, overwhelming, leaving no choice of means, and no moment 


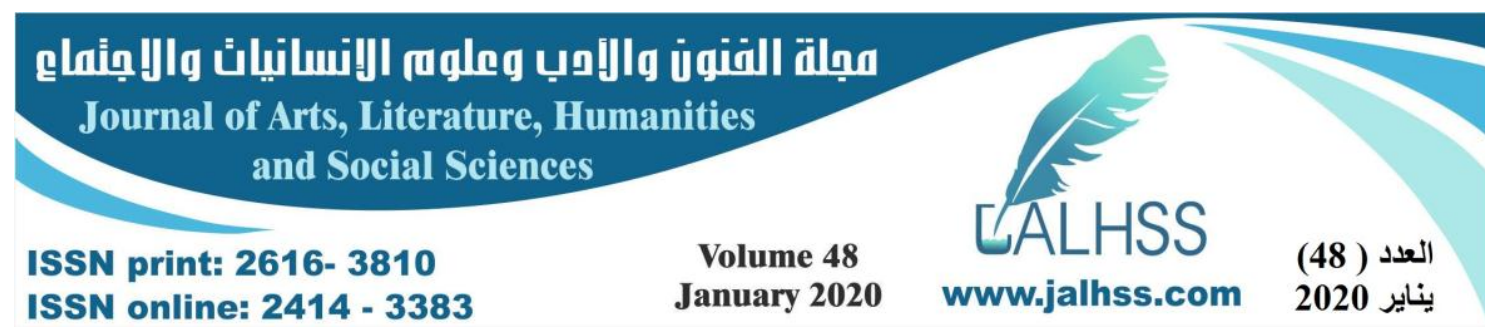

for deliberation......."(Apple, 2012).In addition, the act must not be unreasonable or excessive. This analysis for self-defence which suggested by Webster was achieved acceptance by the UK and it is determined as an expression of the provisions under which a state can exercise the right of self-defence as a customary right (Hillier, 1999, 249).

\section{3- Article 51 and the of Self-Defence}

states have the right of self-defence if an armed attack has taken place. Article 51 has provided this right but all phrases is not absolutely clear, however Article 51 explained that the use of force is permitted if armed attack occurs but it is not responding this situation when it is about to attack. It has been interpreted differently. states have been demanded to refrain the threat or use of force according to Article 2(4), however the Article 51 does not mentioned to self-defence in case of threat of force. It is unclear when the other forbidden acts occurred against a state, this state can use the force as a right of self-defence or this right is just allowed in case of armed attack (Higgins, 1992, 242). The question arises if there is a potential danger what a state must to do, it should wait until an armed attack will occur or it can exercise the right of self-defence before commence an armed attack.

On the on hand, many states and scholars stated that states can resort to selfdefence just if an armed attack had happened. In other words, a state is entitled to use a force when it already has become a victim; it means an attack has been started. On the other hand, others argue if an overwhelming feeling of risk meets a state, it is illogical if they have been required to wait until the armed attack will occur. In this event, they can exercise a right of an anticipatory of self- defence (Abass, 2012, 372).

\section{4- Potential Armed Attack and Self-Defence}

The question will appear can states resort the use of force in anticipation on the grounds of potential armed attack pursuant to article 51. Many discussions have revolved around this article and a number of contradictory beliefs have emerged. Some scholars dispute that the article 51 and article 2 (4) are conjunction, and others arguing that the mentioning inherent right meant the right of self-defence is under customary law and confined by particular provisions in article 51, which mentioned solely to the situation once the armed attack had appended (Shaw, 2008, 1132).

There are other terms have been used as a synonym for anticipatory selfdefence. Anticipatory self-defence and pre-emptive self-defence are considered almost an interchangeable terms, they are military act which perform against an impending attack. In other words, the imminent already exist and it is tangible like deploy troops on board. In contrast, with regard to preventive action, the threat is not near and the act has taken place in early phase against the probable military action which is not in fact materializes. Vaidas Miliauskas defined an anticipatory selfdefence as "use of armed force by a state to replace an imminent threat of an armed attack by another state. Therefore, this type of self-defence envisage a situation where a state has not yet suffered an armed attack but perceives that such a coercive attack is about to happen, in near future"( Miliaukas, 2011, 8). 


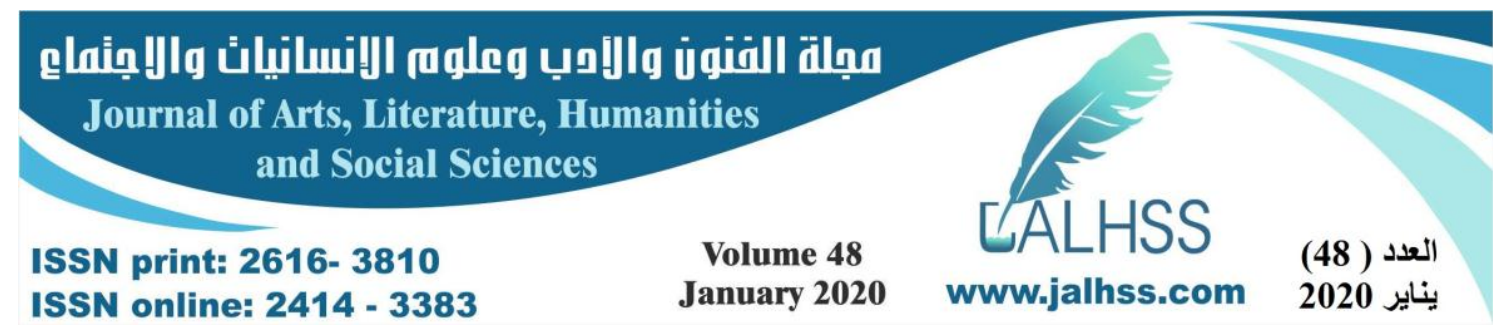

The legality of anticipatory self-defence is one of the contentious issues in public international law. Academic view about this point has divide into schools. Firstly, the expansionist school concentrates on the phrase "inherent right ". It has been argued that when a state meet a massive feeling of risk it is illogical a state has been required to wait until the attack reaches its land. There is a strong belief that the pre-existing right of self-defence which originates from international customer law has not replaced by Article 51.Consequently, the right of self-defence naturally has customary source, but this right has been stipulated in article 51 which includes merely one field of the nation of the self- defence(Andreiase,9-10, http://arno.uvt.nl/show.cgi?fid=122935).

Another argument of the proponents of the expansionist school allege the situations in which self-defence may be practiced this right is not restricted, the word "if" which has been written in article 51 does not mean "if and only if ". According to this justification, a state is entitled to use force in the wide range (Malanczuk, 1997, 312). The right of self-defence under article 51 has a clear meaning so it covers an anticipated armed attack. Furthermore, the nuclear weapons have ability to destroy all defensive capability within a few minutes so it is unreasonable if a state has been complain if it use force as anticipatory self-defence. The UN collective security system was ineffective nature because of the Cold War, so having the right of selfdefence against imminent risk has become needful. It means a state has responsibility to maintain peace and security as long as the UN cannot perform this action (Azubuike, 166-167).

Advocates of expansionism school have deduced from reading article 51 that the use of force is permissible under customary law not only against armed attack, should not be banned. The condition of armed attack was incorporated in the United Nations charter to confirm the Chapultepec Treaty which secures the collective selfdefence (Miliaukas, 2011, 16). Supporters for the restrictive interpretation concentrated on that, the use of force as a means of self-defence has been allowed only in case of armed attack. This analysis led to this conclusion that the anticipatory self-defence is not permissible pursuant the United Nation Charter. It has been justified and supported by three reasons. Firstly, before the right of self-defence was stipulated in UN Charter it was existence as a customary right, whereby States were permitted to use force against an imminent threat.

This right was abolished after the UN Charter came into force. Secondly, the provisions in the UN Charter have regulated the right of self-defence in case of certain aggression. The article 51 should interpret in narrowly and do not be expanded to include anticipatory or pre-emptive self-defence (Miliaukas, 2011 ,13). In addition, this right is permitted temporarily until the sufficient measures have been taken by the Security Council (The United Nations Charter, Article 51). Furthermore, The Security Council is only authorized to decide whether this satiation makes a threat to international peace and security or no. The state which is threatened must demand the Security Council to deal with it and does not resort to military option initially (Miliaukas, 2011, 13-14). 


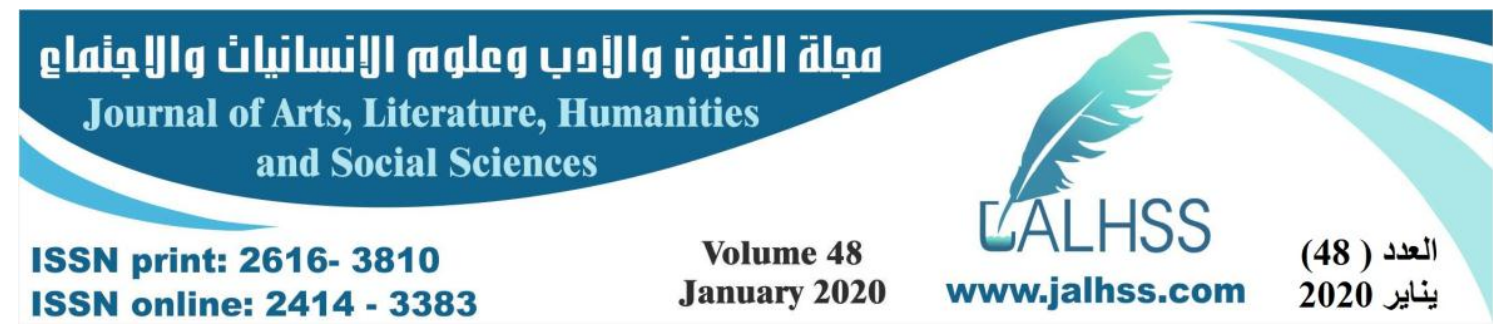

Nothing in article 51 mentions that a state has right to exercise the right of self-defence in other cases rather than an armed attack. The meaning of this article is too obvious so it does not need any wide interpretation. Proponents of restrictive school explain an expectation of an imminent attack is difficult, in the some cases the anticipatory of self-defence may has been expected on the ground of wrong information (Azubuike, 2011, 164-164).

The view of the advocates of the restrictive school has reflected in the United Nations Security Council Resolution 487, 19 June 1981. In 1981 the Iraqi nuclear reactor was attacked by Israel. The former justified its action as self-defence because Iraq directed its nuclear towards Israel. The Security Council condemned this attack through the resolution 487, in which the article 2(4) was referred. This attack was regarded a violation of the Charter and Israel must avoid to use violation in its interrelation in future (Abass, 2012, 372).

\section{5- Anticipatory self-Defence in Contemporary History}

There a number of events happened with regard to anticipatory self-defence and pre-emptive self-defence during the 1962 Cuban Missile Crisis took place. The 'defensive quarantine' was instituted by the US in response to Soviet nuclear missiles on Cuba. The US justified its action on the ground of self-defence even the US actually did not be attacked. During the six day war 1967 some border areas of Arab countries had occupied by Israel on basis of self-defence (Richter, 2013). With regard to contemporary events, in 2003, Iraq was occupied by the US, and in 2007 Israeli air strike carried out against Syria. Both of attacks had been happened on the ground of pre-emptive use of force but were not identical for the Caroline doctrine requirements (Miliaukas, 2011, 38-39). None of these incidents could establish a new customary rule which allows the right of pre-emptive self defence against potential threats, because it is not exercised by sufficient states and there is a deficiency of Jurists opinion. These events are regarded as a starting point for a new discussion about legality of anticipatory self-defence if necessity and proportionality are existence (Miliaukas, 2011, 43).

Nowadays, the question about the legality of anticipatory self-defence has becomes an important matter. Nuclear weapons become as devastating biological weapon possesses by a number of states whereby a state can attack another without crossing the frontier. In addition terrorist operations have become the most dangerous source of attacks on the interests of the states any time without warning (Abass, 2012, 374).

Non-proliferation treats cause to development of nuclear weapons unlawfully and it has become an excuse to use the right of pre-emptive self-defence. All states have the right to use nuclear technology peacefully. On the other hand, if is used illegally will cause severe losses and long-dated diseases (Weise, 2012, 1333).

A new debate has been added to the anticipatory self-defence after 11 September is called the "emerging threat" doctrine or "Bush Doctrine". According to this doctrine the unilateral pre-emptied self-defence might be employed in cases of where the 


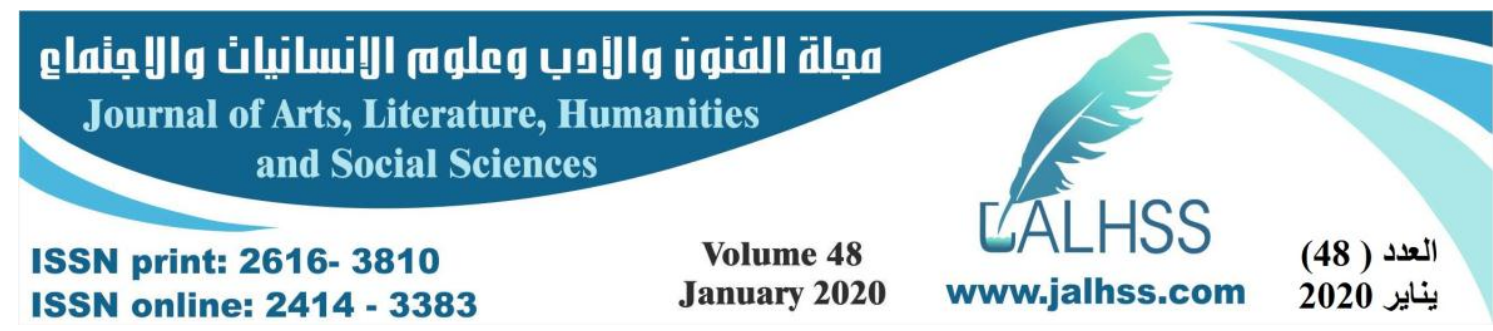

adversary neither took place an attack nor is an attack imminent (Mulcahy \& Mahony, 2006, 236) This doctrine has confirmed there is no difference between the terrorists and who is shelter them. Consequently, the invasion of Afghanistan was taken place in October 2001(Champion, http://isme.tamu.edu/JSCOPE05/Champion05.html). The recent example was in 2003, when the Saddam regime fell down (Richter, 2003).

The military reaction against terrorism in Afghanistan achieved the international agreement as a result 11 September is regarded as turning point in the concept of the right of self-defence. In addition, the contemporary incidents such as 11 September have led to in necessity to completely review the right of the selfdefence (Smith, 2006). The UN Security Council implicitly supported the use of force as anticipatory self-defence by issue Resolution 1373 (28 September).In the content of this resolution was demanded a states to prohibit the perpetration of terrorism actions by exchange information amongst them and taking the necessary step of early warning (Abass, 2011, 377). Actually, the right of anticipatory self-defence has recognised through this resolution because was mentioned to " the inherent right of individual and collective self-defence in accordance with the Charter......". The right of self-defence originates from an international customary law and reaffirmed in article 51 so it does not need consent of the Security Council (Ulfstein, 2003, 154).

The doctrine is released to the United States Congress in September 2002 in following terms by the Bush Administration's National Security Strategy in these following meaning; the concept of imminent threat must be adapted according to recently abilities and purposes of enemy. Adversaries and terrorists do not use a traditional means in their attack as a result to protect against such hostile acts, the United States will resort to pre-emptively if it is necessary (Mulcahy \& Mahony, 2006, 236).

\section{6- International court of just and anticipatory self-defence}

With regard to the ICJ comment about the anticipatory self-defence, it has reflected in Nicaragua v. USA case. The ICJ refuses to pronounce on the anticipatory self-defence because the party focused on the right of self-defence as a subject which related to customary international law and the armed attack already has taken place. In addition the question about the legality of the imminent threat has not been appeared. In terms of nuclear weapon, The ICJ was required by the General Assembly to comment on the anticipatory self-defence The ICJ did not announce its view. The reason might be the Court did not regard the answer is a necessity and it only said that the threat is illegal following the use of force also is unlawful (Abass, 2011, 347-375). The obstacles surround the anticipatory self-defence by distinguishing between the linked treaty and custom. The lawful scope of governing the use of force is sophisticated blend, article 2 (4) is prohibited the use of force, while article 51 is allowed it (Mulcahy \& Mahony, 2006, 232). It must be noted that the international law is not unchangeable but it is flexible and generally depend on state practice. In 21 th century threats to states and public integrity has increased. Consequently, the new applicable method has become necessity to address with the terrorism and weapons of mass destruction. It is expected that the Security Council has been demanded to find a peaceful resolution for security threats, however the delaying 


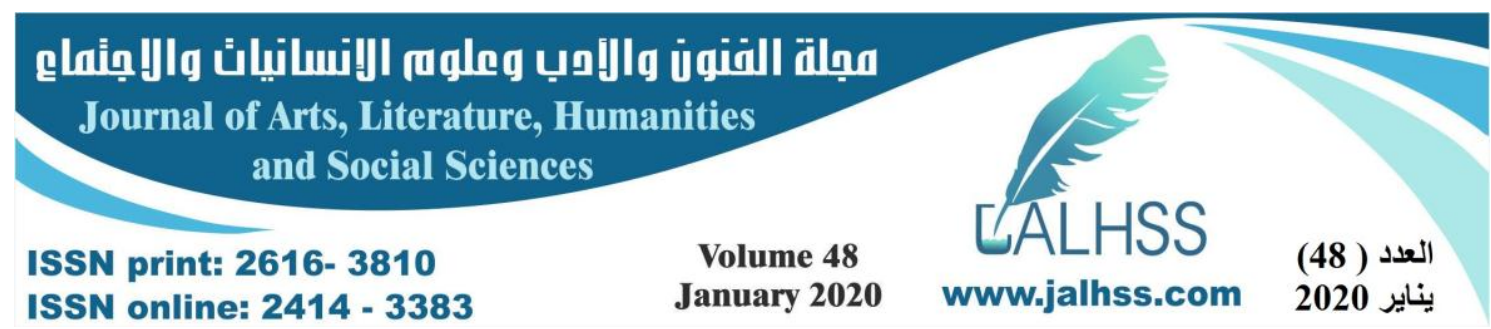

taking sufficient measures has dangerous outcome. Current British justice to the ICJ said "in a nuclear age, common sense cannot require to interpret an ambiguous provision in a way that require a state to passively accept its fate before it can defend itself' ( N. B, 2005).

\section{Conclusion}

The League Nation and the United Nations have role to regulate the use of force in international relation, however it does not make stability in international relations. The right of self-defence has regarded as a long-standing contentious term. On-going debate has been about regarding anticipatory self-defence and pre-emptive self-defence as a part of the right of self-defence. An advocates of expansionism school has reaffirmed the right of anticipatory self-defence originated from the international customer law as an inherent right any treaty cannot abolish this right. Consequently, states can use the force against imminent attack. In addition they depend on the wide Interpretation for the article 51 in the charter so the self-defence can be used in a wide range. In contrast, advocates of restrictive school have asserted that anticipatory self-defence cancelled when the article 51 came into force. They explained that article 51 does not need any more interpretation. The right of anticipatory self-defence has derived from the customary international law which originated from Caroline incident. The United Nation Charter does not embrace any clause support the right of anticipatory self-defence. Furthermore, the ICJ did not pronounce on this right

After 11 September the, attempt is beginning to expand the scope of the right of self-defence, particularly after Bush Doctrine was established. It has been successful to encourage states to make cooperation against terrorist attack. In addition, the proliferation of nuclear weapons in this age has become an excuse for those who support the expansion of self-defence Preventive. Changes and developments that have occurred in the way and gravity of attacks require a revision for definition of the right of the self-defence pursuant Caroline Doctrine, which requires the necessity and proportionality and Article 51, in which armed attack is condition.

Article 51 covers a comprehensive of the cases in which a state can use force as a means of self-defence. Thus, the anticipatory self-defence has been justified by customary rule which was available before the United Nation charter has been legislated. Even the Caroline Doctrine is a good justification to use against contemporary threats like weapons of mass destruction and terrorism, however, it is not easy task to apply Caroline standard at present and may it be abuse these rights by strong States for their interests. 


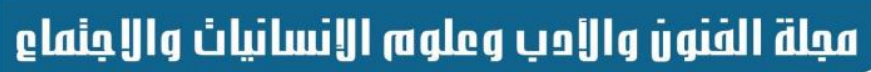

Journal of Arts, Literature, Humanities

and Social Sciences

ISSN print: 2616- 3810

Volume 48

ISSN online: 2414 - 3383

January 2020

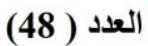

www.jalhss.com

يناير 2020

\section{References}

\section{Books}

1. Abass. Ademola, (2012). Complete International Law Text, Cases, and Materials, Oxford University States, the United States.

2. Aust, A., (2010). Handbook of International Law, (2 ${ }^{\text {nd }}$ ed), Cambridge University Press, the United Stated.

3. Higgins, R., (1994). Problems and Process International Law and How We Uses It, $\left(1^{\text {st }}\right.$ ed $)$, Oxford University Press, the United Kingdom.

4. Hillier, T., (1998). Sourcebook on Public International Law, ( $1^{\text {st }}$ ed), Cavendish Publishing Limited, Great Britain.

5. Hillier, T., (1999). Principles of Public International Law, $\left(2^{\text {nd }}\right.$ ed), Cavendish Publish Limited, the United Kingdom.

6. Malanczuk, P., (1997). Akehurst's Modern Introduction to International Law, $\left(7^{\text {th }}\right.$ ed), Routledge, London.

7. Mendum, A., \& Waugy, S., (2001). Revise Modern World History, ( $1^{\text {st }}$ ed), the United States, Heinemann Education Publishers.

8. Shaw, M., (2008). International Law, (6 ${ }^{\text {th }}$ ed), CUP.

9. Szabo, K., (2011). Anticipatory Action in self-Defence, (T.M.C .Asser Press, The Netherland.

10. Wallace, R., (2005). International Law, (5 $5^{\text {th }}$ ed) Sweet\& Maxwell Limited, London.

11. Webb, P., (2013). International Judicial integration and Fragmentation, $\left(1^{\mathrm{st}} \mathrm{ed}\right)$, Oxford University Press, the United Kingdom.

\section{Articles}

1- Azubuike, E., (2011). Probing the Scope OF Self Defence in International Law. http://digitalcommons.law.ggu.edu/cgi/viewcontent.cgi?article $=1150 \&$ context $=$ ann $\underline{\text { lsurvey }}$

1. Apple, J., (2012). Origin of Definition of "Necessity" in the International Law of Self Defence -the Caroline Affair, International Judicial Academy, Washington, D.C., with assistance from the American Society of International Law, Spring, 2012.

http://www.judicialmonitor.org/archive spring2012/historic.html

2. Richter, C., (2003). Pre-emptive Self-Defence, International Law and US Policy, http://www.polsis.uq.edu.au/dialogue/vol-1-2-6.pdf

3. Weise, R., (2012). How Nuclear Weapons Change the Doctrine of Self-Defence. http://nyujilp.org/wp-content/uploads/2013/02/44.4-Weise.pdf

4. Mulcahy, J., \& Mahony, C., (2006). Anticipatory Self-Defence: A Discussion of the International Law.

http://www.hanselawreview.org/pdf4/Vol2No2Art06.pdf

5. Smith, I., Terrorism, (2006). Pre-emptive Self-defence and State Interests: What Challenges for Contemporary International Legal Order?, Amicus Curiae, (Issue 67), Madrid. http://sas-space.sas.ac.uk/2933/1/Amicus67_Smith.pdf 


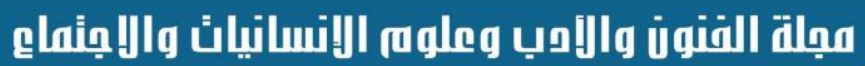 \\ Journal of Arts, Literature, Humanities \\ and Social Sciences}

ISSN print: 2616- 3810

Volume 48

ISSN online: $2414-3383$

January 2020

6. Ulfstein, G., (2003). Terrorism and the Use of Force, SAGE.

http://www.sagepub.com/martin3study/articles/Ulfstein.pdf

7. N. B, (2005). Anticipatory of Self-Defence in the $21^{\text {st }}$ Century, the Centre for Random Rantage, November 21, at 3:50 PM

http://worldpolitiks.blogspot.co.uk/2005/06/anticipatory-self-defense-in-21st.html

8. Fitzgerald, M., (2008). Seizing Weapons of Mass Destruction from ForeignFlagged Ships on the High Seas Under Article 51 of the UN Charter, (Volume $49-$ Issue 2), the Virginia Journal of International Law Association, For reprint permissions. http://www.vjil.org/assets/pdfs/vol49/issue2/49_473-505.pdf

\section{Other Sources:}

1. Pre-emptive Action No. 36, AIV/No. 15, CAVV, July 2004. http://www.aiv-advies.nl/ContentSuite/upload/aiv/doc/nr36eng(1).pdf

2. Miliaukas, V., 2011, Whether International Law Allows pre-emptive Use of Force. http://vddb.library.lt/fedora/get/LT-eLABa0001:E.02 2011 D_20110622_172449- 22004/DS.005.1.01.ETD.

3. Andreiase, V., n.d, Anticipatory Self-Defence in International Law; legal or just a Construct for using force? http://arno.uvt.nl/show.cgi?fid=122935

4. Champion, S., Anticipatory (Pre-emptive) Self-defence: The Need for a Modern Approach. http://isme.tamu.edu/JSCOPE05/Champion05.html 